\title{
The War Crime of Committing Outrages upon Human Dignity and Degrading Treatment
}

\author{
Ali Mohebi ${ }^{1} \&$ Esmaeel Afrasiabi ${ }^{2}$ \\ ${ }^{1} \mathrm{PhD}$ Candidate of criminal Law, Islamic Azad University Central Tehran Branech \\ ${ }^{2} \mathrm{PhD}$ of criminal Law-Assistants of professor, Islamic Azad University Central Tehran Branech
}

Received: May 29, 2017

doi:10.5539/ass.v13n8p135
Accepted: June 14, $2017 \quad$ Online Published: July 25, 2017

URL: https://doi.org/10.5539/ass.v13n8p135

\begin{abstract}
The present paper seeks to discuss the war crime of committing outrages upon human dignity, in particular humiliating and degrading treatment. This crime is defined in Article 8(2)(b)(xxi) of the International Criminal Court Statute. Although the war crimes perpetrated in Camp 9 of Iraq are not limited to outrages upon human dignity, in particular humiliating and degrading treatment, this crime was selected to be studied here based on several criteria: first, it was inflicted upon all prisoners; second, it was practiced for the entire period of our imprisonment, i.e. four and a half years; third, it was explicit and obvious; and fourth, all prisoners were victimized by this crime. Humiliating and degrading treatment here refers to a lack of lavatories within the dormitories of the camp which brought about degrading and immoral consequences. Unfortunately, the officers of the Red Cross who frequently visited the camp took no measure to solve the problem
\end{abstract}

Keywords: prisoners of war, war crime, human dignity, degrading behavior

\section{Research Questions and Hypotheses}

1. Is it possible to consider the lack of lavatories within the dormitories of a prisoners' camp as an instance of committing outrages upon human dignity, in particular humiliating and degrading treatment, according to Article $8(2)(b)(x x i)$ of the International Criminal Court Statute?

2. Is the long-term suffering caused by deprivation of lavatory not an instance of torture or inhuman treatment?

Our hypothesis is that this crime is a war crime of committing outrages upon human dignity, in particular humiliating and degrading treatment. It is also hypothesized that the long-term suffering caused by deprivation of lavatory is an instance of torture or, at least, inhuman treatment which is regarded as a war crime in the International Criminal Court Statute.

\section{Objectives of the Research}

War crimes mentioned in the International Criminal Court Statute are sometimes vague in terms of their instances. For instance, I was a prisoner of war in Camp 9 of Iraq for about four and a half years. Our dormitory did not have a separate lavatory and every night from $7 \mathrm{pm}$ until 7 the doors were locked, preventing us from having access to lavatory for 12 hours. It was a serious suffering and usually led to situations where prisoners would be humiliated by others. It seems that this is an instance of war crime whereas the International Criminal Court Statute does not explicitly address this issue The significance of this topic lies in our answer to the question as to whether this can be regarded as a war crime or not. If the answer is positive, the instances of war crimes in international documents need further revision and should incorporate this issue. Moreover, during the four and a half years when about 1200 prisoners lived in extremely difficult conditions, Red Cross officers regularly visited Camp 9 and did not take any specific measure. Thus, a clearer anticipation of the different types of war crime in the International Criminal Court Statute may, on the one hand, specify the obligations of the detaining power with regard to the internment of the prisoners and, on the other hand, help institutions like Red Cross to remind the detaining power of its offences and generate a comprehensive report of the violations of the rights of the prisoners which take the form of a war crime.

\section{Definition of War Crime}

War crime refers to disobedience against the international principles of humanitarian law. As a criminal phenomenon, war crime is regarded as an international crime. War crime was for the first time defined in Hague 
Convention of 1907 with regard to the laws and customs of war ${ }^{1}$. War crimes occur in armed conflicts; however, not every crime in an armed conflict should be taken as a war crime. A crime must be sufficiently dependent on the armed conflict to be considered a war crime.

The war crimes mentioned within the charters of Nuremberg and Tokyo trials had been committed during international armed conflicts. Paragraph (b) of Article 6 of Nuremberg Charter defines war crime as following:

War crimes: namely, violations of the laws or customs of war. Such violations shall include, but not be limited to, murder, ill-treatment or deportation to Wave labour or for any other purpose of civilian population of or in occupied territory, murder or ill-treatment of prisoners of war or persons on the seas, killing of hostages, plunder of public or private property, wanton destruction of cities, towns or villages, or devastation not justified by military necessity. ${ }^{2}$

The war crimes mentioned in the statute of the International Criminal Tribunal for the former Yugoslavia (ICTY) are divided into two types. Article 2 of this statute addresses the prohibition of grave breaches of the Geneva Conventions of 1949 which concern support for the victims of international armed conflicts. Article 3 prohibits violations of laws or customs of war and states that these violations are potentially unlimited, only sufficing to mention a few examples. This article seeks to go beyond grave breaches by addressing all serious crimes, thereby playing the role of a so-called 'general principle'. On this basis, crimes such as torture or humiliation, although not explicitly mentioned, should fall into the category of war crimes.

War crime as defined in the statute of the International Criminal Tribunal for Rwanda (ICTR) should be construed in the context of a domestic war. The title of Article 4 of this statute is 'Violations of Article 3 common to the Geneva Conventions and of Additional Protocol II'3.

War crimes can be divided into two types:

1) International war crimes that may be considered as grave breaches of the Geneva Conventions of 1949;

2) War crimes that occur within the domestic jurisdiction of a country and are breaches of Article 3 of the Geneva Conventions of 1949 as well as of other laws or customs which can be applied to non-international armed conflicts. ${ }^{4}$

\section{A Description of Humiliating and Degrading Treatment due to the Lack of Lavatories in the Dormitories of Camp 9}

In order to depict a realistic picture of the crime of humiliating and degrading treatment due to the lack of lavatories in the dormitories of Camp 9 in Iraq, the situation should be described in detail. In what follows, the author seeks to give a detailed description of what happened to the Iranian prisoners of Iran-Iraq war in Camp 9 in Ramadiyah.

\section{-The Capacity of the Dormitories}

There were approximately 50 people in each dormitory. This number of people was too large given that the size of the rooms was 13 by 5 meters. Lack of enough space usually led to considerable difficulties in sleeping. Each person had one pillow and two blankets, one blanket as bedding and the other as covering. Apart from the thin blanket, there was no other mat to cover the floor. 25 people had spread their blanket on the right side of the room and 25 people on the left. About 1.5 meters on each side could not be used because one side incorporated the entrance door and on the other side there was a lavatory chamber made by hanging a blanket. In the middle of the room, a space with a width of $1.2 \mathrm{~m}$ along the length of the room was reserved as a passage.

\section{-Lack of Lavatories within the Dormitories}

Camp 9 accommodated 1200 prisoners and had three divisions, each containing 400 people. There was not any lavatory within the dormitories; rather, ten lavatories were located in the outdoor space of each division. One or two of the lavatories were usually unusable due to the blockage of the sewage pipes. From 7 p.m. until 7 a.m., the prisoners were locked in the dormitories and were not permitted to use the lavatories. It was possible to use

\footnotetext{
${ }^{1}$ Javani, J. Barrasi-ye Jenayat-e Jangi dar Asasnameh-ye Divan-e Keifari-ye Beinolmelali [A Study of War Crimes in the Charter of the International Criminal Court]. The Central Branch of Islamic Azad University of Tehran, Iran. p. 123.

${ }^{2}$ Javani, J. Barrasi-ye Jenayat-e Jangi dar Asasnameh-ye Divan-e Keifari-ye Beinolmelali [A Study of War Crimes in the Charter of the International Criminal Court]. The Central Branch of Islamic Azad University of Tehran, Iran. p. 123.

${ }^{3}$ Kittichaisaree, K. International Criminal Law. Translated by B. Yousefian and M. Esmaeeli (1383/2004) into Persian as Hoghough-e Beynolmelali-ye Keifari, Tehran: Samt, pp. 255-256.

${ }^{4}$ Momtaz, J. and A.H. Ranjbariyan. Hoghough-e Beynolmelal-e Bashardoustaneh: Mokhasemat-e Mosllahaneh-ye Dakheli [International Human Rights: Domestic Armed Conflicts]. Tehran: Mizan, 2006, p. 198 and pp. 204-205.
} 
the blanket-made chambers within our room that could only be used for urination and not for excretion. The lack of lavatories inside the dormitory was certainly one of the mental and physical tortures we suffered in Iraqi prisons and, in many cases, resulted in serious health problems. For twelve hours a day, nobody was allowed to use the lavatories. Inside the dormitory, there was only a pail to be used for urination. Therefore, excretion in the dormitory, in addition to being a punishable offense, brought disgrace upon the person.

As Article 22 of Geneva Convention (III) of 1949 puts is:

Prisoners of war may be interned only in premises located on land and affording every guarantee of hygiene and healthfulness. Except in particular cases which are justified by the interest of the prisoners themselves, they shall not be interned in penitentiaries. Prisoners of war interned in unhealthy areas, or where the climate is injurious for them, shall be removed as soon as possible to a more favourable climate. [...]

Also, Article 25 of this convention states that,

Prisoners of war shall be quartered under conditions as favourable as those for the forces of the Detaining Power who are billeted in the same area. The said conditions shall make allowance for the habits and customs of the prisoners and shall in no case be prejudicial to their health.

The foregoing provisions shall apply in particular to the dormitories of prisoners of war as regards both total surface and minimum cubic space, and the general installations, bedding and blankets.

The premises provided for the use of prisoners of war individually or collectively, shall be entirely protected from dampness and adequately heated and lighted, in particular between dusk and lights out. All precautions must be taken against the danger of fire.

In any camps in which women prisoners of war, as well as men, are accommodated, separate dormitories shall be provided for them.

Violation of the above articles had led to a difficult situation where all of us faced serious physical and mental problems due to the lack of access to lavatories for a period of 12 hours that was preceded by eating dinner. For more than four years, every morning the 400 prisoners of each division of Camp 9 rushed to reach the lavatories sooner than their fellow prisoners. As there were only 10 lavatories, the ratio of lavatories to individuals was 1 to 40; that is, a queue of 40 waited for each lavatory. The lavatory building, however, did not have the capacity for this number of people. As a result, prisoners from the dormitories that were located farther to the lavatories usually arrived later and were compelled either to wait for their turn in the yard or to use the others' turn. The latter was often not possible because all of us were equally under physical pressure. Iraqi guards watched this scene every day for four years and six months, but they did not take any measure to solve the problem.

\section{-Serious Problems in Ramadan}

For those who have grown up in the lap of luxury it is not imaginable how one can put with a lack of access to lavatory for 12 hours a day, but the negative physical consequences are obvious and undeniable. However, we had got accustomed to the situation in ordinary days when we had only one meal, namely dinner, during the night. In Ramadan, another meal called 'sahari' is served by Muslims before the sunrise ${ }^{5}$. Eating two meals without being allowed to use the lavatories was a real torture. As mentioned above, the door of the dormitory could not be opened even by the senior officer of the dormitory. In cases like acute diseases where urgent actions needed to be taken, the door could be opened only by the order of the general commander of the camp.

In Ramadan, we were not provided with a separate meal for sahari; rather we put aside the lunch, which a fasting Muslim should not eat, for our sahari. What was particularly difficult was that we took two meals during the night and were not allowed to use the lavatory. The only thing to be used was the pail for urination inside the room. There was no exception to this rule even in the month of Ramadan. Using this pail for excretion was a punishable act as well as a serious humiliation among our fellow prisoners. All of us constantly tried not to use the pail for excretion; however, the need to empty waste material from your body is sometimes so urgent that you cannot think about face-saving and respect.

The reader of this paper may find it rude to talk about the details, but I seek to illustrate one of the most intolerable types of physical and mental torture for those who have not experienced a similar situation. The pain of the lashes of a whip may not last more than a couple of minutes and will not bring about severe mental consequences whereas the above situation leads to negative health problems as well as humiliation and serious

\footnotetext{
${ }^{5}$ In the month of Ramadan, Muslims take two meals: one is the dinner and the other is called 'sahari' in Persian. Sahari is served before the sunrise. Muslims fast during the day from the sunrise until the sunset.
} 
mental problems that may last forever. As with human rights, the most basic rights for prisoners of war that have been internationally recognized in Geneva Convention III of 1949 are healthy conditions. During four and a half years, however, we were deprived of healthy conditions. This is why all of the details of such diaries should be faithfully and accurately related and recorded in order to be used in scholarly investigations of the history of Iran-Iraq war.

As I did not want to be exposed to the obscenity of the television, I decided to stay next to the blanket-made lavatory within the room throughout the four years of my imprisonment. I believed that tolerating the disgusting reek of urine would be better than watching the obscene programs on television. In the following, I shall relate one of the things that happened to me during the four years of my proximity to the blanket-made lavatory of the dormitory. This story is of course relevant to our discussion here.

There was a small store in the camp where the prisoners could buy what they needed by their monthly salary which was 1.5 dinars. Instead of natural milk, the store sold powdered milk. A number of smart prisoners had come up with the idea that they could keep the empty milk cans for excretion in urgent cases. When all prisoners were asleep, they excreted and put their feces into the can. After closing its lid, they put it behind the blanket walls of the lavatory. The next morning, they went out earlier than others to dispose of the can by putting it into the refuse containers. Some of the prisoners had come to know this trick, but they did not reveal it because they understood how difficult the situation was. One night at about ten o'clock, the sound of an explosion filled the room and the lid of a can hit the ceiling. It was then discovered that one of the prisoners had forgotten to empty the can and the gas released from the feces into the closed can after 20 hours had caused the explosion. This story might now seem funny and trivial, but the person guilty of this act was finally spotted and teased by other prisoners, which was an unbearable mental suffering and disgrace.

Sometimes a prisoner happened to be in urgent need of excretion and hurriedly ran into the blanket-made lavatory to empty his bowels. It resulted in clumsy situation and subsequent humiliation for the person. In many such cases, the rudimentary rights of Iranian prisoners in Iraq were neglected. These real aspects of the life of Iranian prisoners in Iraqi prisons must not be forgotten. They should be related in clear details by those who have experienced imprisonment in Iran-Iraq war so as to reveal Ba'ath regime's inhuman treatment of Iranian prisoners.

I have also a personal unpleasant experience to support my arguments. One night at two o'clock, I developed severe diarrhea. I knew very well that I could not wait until morning for the doors to be opened. So I decided to relieve myself from the suffering, but I could not put up with humiliation and loss of respect. After all, it is understandable that all fellow prisoners are not friends, some of them developing enmity due to the difficult life in prison and waiting for opportunities to mock their enemies. What is more, the news of my disgrace would certainly go beyond the dormitory and spread all over the camp. Therefore, I had previously thought about what to do if I would have become stuck in such a situation. I tried to dissolve the feces into the urine pail by my hand in a way that nobody would discover it. Although the color of the urine was likely to change, it was the only way for me to avoid humiliation. No doubt I committed a nauseating act, but it was worth saving face and respect.

\section{Three Elements of the Crime of Humiliation and Degrading Treatment}

I. Legal element

1. The statute of ICTY

2. The charters of Nuremberg and Tokyo trials

3. War crimes mentioned in the statute of ICTR

4. The International Criminal Court Statute

5. European Commission on Human Rights

6. International Humanitarian Law

War crimes mentioned in the International Criminal Court Statute are divided into four types according to Article 8 of the statute:

1. Grave breaches of the Geneva Conventions of 12 August 1949;

2. Other serious violations of the laws and customs applicable in international armed conflict, within the established framework of international law;

3. In the case of an armed conflict not of an international character, serious violations of article 3 common to the four Geneva Conventions of 12 August 1949; 
4. Other serious violations of the laws and customs applicable in armed conflicts not of an international character, within the established framework of international law. ${ }^{6}$

Although references are made in the present paper to the trials of Yugoslavia, Nuremberg, etc. in order to shed light on the crimes of humiliation and degrading treatment, what is the basis of our arguments is the International Criminal Court Statute. Moreover, as inhuman treatment is closely related to humiliating and degrading treatment, the former is also discussed here so that we could compare both crimes and conclude as to which one may cover the consequences of the lack of lavatories within Camp 9.

- Committing outrages upon personal dignity, in particular humiliating and degrading treatment (Article $8(2)(b)(x x i)$ of the ICC Statute)

(Approved in the first session of the Assembly of State Parties to the Rome Statute)

1. The perpetrator humiliated, degraded or otherwise violated the dignity of one or more persons.

2. The severity of the humiliation, degradation or other violation was of such degree as to be generally recognized as an outrage upon personal dignity.

3. The conduct took place in the context of and was associated with an international armed conflict.

4. The perpetrator was aware of factual circumstances that established the existence of an armed conflict.

\section{-Inhuman treatment (Article 8(2)(a)(II) of the ICC Statute)}

1. The perpetrator inflicted severe physical or mental pain or suffering upon one or more persons.

2. Such person or persons were protected under one or more of the Geneva Conventions of 1949.

3. The perpetrator was aware of the factual circumstances that established that protected status.

4. The conduct took place in the context of and was associated with an international armed conflict.

5. The perpetrator was aware of factual circumstances that established the existence of an armed conflict.

\section{Element of Criminal Conduct (Actus Reus)}

The actus reus of this crime may be in form of act or omission. Act is more obviously an instance of criminal conduct, e.g. offensive behavior or swearing, in which case the crime is directly committed by the perpetrator toward the victim. In order to take into account omission as an instance of crime, a number of legal obligations should be anticipated for the perpetrator so that any violation of these obligations could be considered as a crime. In other words, legal obligations are essential to the definition of crime as omission. As mentioned earlier, international laws, in particular the ICC statute, stipulate a number of obligations for the detaining powers. Any negligence of these obligations would, on the one hand, cause violation of prisoners' rights and, on the other hand, lead to commission of a war crime. As discussed above, Articles 22 and 25 of Geneva Convention (III) of 1949 state that war prisoners must be interned by the detaining power within proper camps with necessary facilities. There is no doubt that establishing a lavatory within a dormitory that is locked for 12 hours should be considered one of the necessary facilities. Therefore, depriving the prisoners of lavatory within the dormitory and its degrading consequences is an obvious instance of omission and a crime of humiliating and degrading treatment.

As with the actus reus, all persons can be criminally liable for perpetration of war crimes. Principally every crime should be dealt with as an individual case so that civilians can also be liable for war crimes ${ }^{7}$. Furthermore, any act or omission that violates International Humanitarian Law ${ }^{8}$ may be regarded as the actus reus of these crimes.

The term 'in particular' used in the wording of this crime within the text of the Statute implies that degrading treatment is part of the larger category of committing outrages upon human dignity 9 .

According to the first assembly, the actus reus of this crime is humiliation, degradation, or any other similar conduct that disgraces human dignity. Use of the term 'in particular' in Article 8(2)(b)(xxi) of the ICC Statute implies the fact that humiliation and degradation are considered in the Statute as instances of committing

\footnotetext{
6در اينجا شما به منبع فارسى ارجاع داده ايد كه ترجمه قو انين را از آن آورده ايد، ولى از آنجا كه بنده اصل انكليسى قو انين را آورده ام، قاعدتا ديكر به منبع فارسى نيازى نيست.

${ }^{7}$ Kittichaisaree, K. International Criminal Law. Translated by B. Yousefian and M. Esmaeeli (1383/2004) into Persian as Hoghough-e Beynolmelali-ye Keifari, Tehran: Samt, p. 258.

${ }^{8}$ Javani, J. Barrasi-ye Jenayat-e Jangi dar Asasnameh-ye Divan-e Keifari-ye Beinolmelali [A Study of War Crimes in the Charter of the International Criminal Court]. The Central Branch of Islamic Azad University of Tehran, Iran. p. 122.

${ }^{9}$ ICTY, Judgment, The Prosecutor v. AntoFurunszija, IT.95-17/1-T.para.186.p.73;121 ILR 218 at 272.
} 
outrages upon human dignity. The phrase 'or otherwise violated the dignity of one or more persons' in Paragraph 1 seeks to extend the scope this crime beyond degrading and humiliating and cover other types of violation of human dignity. A treatment is considered degrading only if a sufficiently severe degradation or humiliation is inflicted upon the victim before their eyes or other persons ${ }^{10}$.

In determining whether a treatment is severe enough to be called an outrage upon human dignity, relevant aspects of the cultural background of the victim should also be taken into account. As the degree of degradation or humiliation of the victim often depends on their cultural background, this consideration is mentioned in the Statute ${ }^{11}$.

Cultural beliefs play a major role in determining violation of human dignity since cultural and moral values with which an individual grows up actually form their personality. The degrading consequences of the lack of lavatory in the dormitories of Camp 9 for Iranian prisoners may seem less severe in other cultural contexts. However, Iranian culture conceives this punishment as an instance of immoral treatment.

There are many examples concerning cultural beliefs that have been widely discussed in international forums. For instance, the detaining power may force the victim to eat something that is prohibited in their religion. Another example which is related to the cases of World War II ${ }^{12}$ is the shaving of the hair and beard of sikh prisoners and compelling them to smoke given that these acts are prohibited in Sikhism.

This treatment should incorporate the purpose mentioned for this crime, i.e. violation of human dignity. In this regard, the ICTY states that,

An outrage upon personal dignity within Article 3 of the Statute is a species of inhuman treatment that is deplorable, occasioning more serious suffering than most prohibited acts falling within the genus. 75 It is unquestionable that the prohibition of acts constituting outrages upon personal dignity safeguards an important value. Indeed, it is difficult to conceive of a more important value than that of respect for the human personality. ${ }^{13}$

As the prosecutor of ICTY puts it, "protection of human dignity includes prohibition of any act or omission that degrades, humiliates, or attacks victim's personality, in particular sexual personality"14.

In this regard, ICTY states the following in the case of Aleksovski:

An outrage upon personal dignity is an act which is animated by contempt for the human dignity of another person. The corollary is that the act must cause serious humiliation or degradation to the victim. It is not necessary for the act to directly harm the physical or mental well-being of the victim. It is enough that the act causes real and lasting suffering to the individual arising from the humiliation or ridicule. The degree of suffering which the victim endures will obviously depend on his/her temperament. Sensitive individuals tend to be more prone to perceive their treatment by others to be humiliating and, in addition, they tend to suffer from the effects thereof more grievously. On the other hand, the perpetrator would be hard-pressed to cause serious distress to individuals with nonchalant dispositions because such persons are not as preoccupied with their treatment by others and, even should they find that treatment to be humiliating, they tend to be able to cope better by shrugging it off. Thus, the same act by a perpetrator may cause intense suffering to the former, but inconsequential discomfort to the latter. This difference in result is occasioned by the subjective element. ${ }^{15}$

In Prosecutor v. Elektrovski16, the prosecutor of ICTY built upon the commentary of the International Committee of the Red Cross on Article 75 of the First Additional Protocol as well as upon the previous data of ICTY on this case ${ }^{17}$ and describes outrages upon human dignity, in particular humiliating and degrading treatment as well as enforced prostitution, as following:

${ }^{10}$ ECtHR Case of Campbell and Consans, Publication of the European Court of Human Rights ,Series A; Judgaments and Decisions, vol, 48,p.13;67ILR480at 492 .

${ }^{11}$ International Committee of the Red Cross and Iranian National Committee of Humanitarian Law, Anasor-e Janayat-e Jangi dar Asasnameh-ye Divan-e Beynolmelali-ye Keifari [Elements of War Crimes in the International Criminal Court Statute], Tehran: Majd Publication, 1393/2014.

12 Tanaka Chuichi and Other Case, in UNWCC, LRTWC, vol. XIII.pp.62 ff;13AD289.

${ }^{13}$ ICTY, Judgment, The Prosecutor v. Zlatko Aleksovski, IT.95-14/1-T.para.54.

${ }^{14}$ ICTY, Prosecutor's Pre-trial Brief, The Prosecutor v. Dragoljub Kunarac, IT.96-23-PT.PP.28ff.

${ }^{15}$ ICTY, Judgment, The Prosecutor v. Zlatko Aleksovski, IT.95-14/1-T.para.56.

${ }^{16}$ ICTY, Prosecutor's Closing Brief, The Prosecutor v. Zlatko Aleksovski, IT.95-14/1-PT.para56, p.23.

${ }^{17}$ ICTY, Judgment, The Prosecutor v. Zlatko Aleksovski, IT.95-14/1-T.para.55. 
Outrages upon personal dignity refer to acts which, without directly causing harm to the integrity and physical and mental well-being of persons, are aimed at humiliating and ridiculing them.

Here are several instances of outrages upon human dignity and degrading treatment due to the lack of lavatory within the dormitories of Camp 9:

1. Hanging blankets in the corner of the room and putting a pail in it to be used for urination.

2. Lack of access to the outdoor lavatories of the camp during a 12-hour period from $7 \mathrm{pm}$ to $7 \mathrm{am}$.

3. Prohibition of using the pail for emptying one's bowels under physical pressure as well as humiliation and degradation of those who could not avoid excretion.

4. Sometimes, the person who used the urination pail for feces was handed to the guard of the dormitory and was punished or, at least, humiliated in the public.

5. It was not uncommon to see nervous prisoners in the morning who were restlessly moving to and fro and waiting for the doors to be opened in order to reach the lavatory.

6. The rushing of 400 prisoners into the lavatories every morning for four and a half years who were sometimes teased by Iraqi guards.

7. The small number of lavatories as well as the limited capacity of the building resulted in a crowd behind the doors and those who arrived later had to wait for their turn in the yard.

8. It was sometimes the case that a prisoner could not tolerate the pressure of feces at night and quickly ran toward the urination pail in the corner of the room.

The above instances are reflected in numerous articles of Geneva Conventions (common Article 3; Articles 1418 and $52^{19}$ of Convention II; and Article $27^{20}$ of Convention IV).

With regard to long-time suffering, the Trial Chamber of Yugoslavia adopted a different approach in the case of Kunarac and others:

Insofar as this definition provides that an outrage upon personal dignity is an act which "cause[s] serious humiliation or degradation to the victim", the Trial Chamber agrees with it. However, the Trial Chamber would not agree with any indication from the passage above that this humiliation or degradation must cause "lasting suffering"1222 to the victim. So long as the humiliation or degradation is real and serious, the Trial Chamber can see no reason why it would also have to be "lasting". In the view of the Trial Chamber, it is not open to regard the fact that a victim has recovered or is overcoming the effects of such an offence as indicating of itself that the relevant acts did not constitute an outrage upon personal dignity. Obviously, if the humiliation and suffering caused is only fleeting in nature, it may be difficult to accept that it is real and serious. However this does not suggest that any sort of minimum temporal requirement of the effects of an outrage upon personal dignity is an element of the offence. ${ }^{21}$

However, given the issues put forward in the case of Aleksovski concerning the measurement of the existence of degradation or humiliation, the Trial Chamber concluded that a purely subjective assessment would be unfair to

\footnotetext{
${ }^{18}$ Article 14-Prisoners of war are entitled in all circumstances to respect for their persons and their honour.

Women shall be treated with all the regard due to their sex and shall in all cases benefit by treatment as favourable as that granted to men.

Prisoners of war shall retain the full civil capacity which they enjoyed at the time of their capture. The Detaining Power may not restrict the exercise, either within or without its own territory, of the rights such capacity confers except in so far as the captivity requires.

${ }_{19}$ Article 52 (2) -No prisoner of war shall be assigned to labour which would be looked upon as humiliating for a member of the Detaining Power's own forces.

The reader may also refer to Article 95 (1) of Geneva Convention (IV) which states that:

The Detaining Power shall not employ internees as workers, unless they so desire. [...] and employment on work which is of a degrading or humiliating character are in any case prohibited.

${ }^{20}$ Article 27-Protected persons are entitled, in all circumstances, to respect for their persons, their honour, their family rights, their religious convictions and practices, and their manners and customs. They shall at all times be humanely treated, and shall be protected especially against all acts of violence or threats thereof and against insults and public curiosity.

Women shall be especially protected against any attack on their honour, in particular against rape, enforced prostitution, or any form of indecent assault.

Without prejudice to the provisions relating to their state of health, age and sex, all protected persons shall be treated with the same consideration by the Party to the conflict in whose power they are, without any adverse distinction based, in particular, on race, religion or political opinion.

${ }^{21}$ ICTY, Judgment, The Prosecutor v. Dragoljub Kunarac and Others, IT.96-23 and IT 96-23/1-T.para.501.
} 
the accused because the accused's culpability would be made to depend not on the gravity of the act but on the sensitivity of the victim ${ }^{22}$.

On this basis, the Trial Chamber understood an outrage upon personal dignity to be any act or omission which would be generally considered to cause serious humiliation, degradation or otherwise be a serious attack on human dignity 23 .

Furthermore, in the case of Aleksovski, the court provided criteria for determining the seriousness of this of an act:

Indeed, the seriousness of an act and its consequences may arise either from the nature of the act per se or from the repetition of an act or from a combination of different acts which, taken individually, would not constitute a crime within the meaning of Article 3 of the Statute. The form, severity and duration of the violence, the intensity and duration of the physical or mental suffering, shall serve as a basis for assessing whether crimes were committed.24

\section{-European Commission on Human Rights}

Considering the different forms of ill-treatment provided in Article 3 of the European Convention on Human Rights, European Court of Human Rights stated that,

Ill-treatment must attain a minimum level of severity if it is to fall within the scope of Article 3 (art. 3). The assessment of this minimum is, in the nature of things, relative; it depends on all the circumstances of the case, such as the duration of the treatment, its physical or mental effects and, in some cases, the sex, age and state of health of the victim, etc. ${ }^{25}$

Degrading treatment, in particular, was first defined according to the European Convention on Human Rights in the Greek case as following: "Degrading treatment or punishment is that which results in debasing the victim explicitly before others or driving the victim to act against his will or conscience"26.

Subsequently, in the case of Ireland v. UK, the European Court of Human Rights specified five techniques of interrogation as degrading. "The techniques were degrading since they were such as to arouse in their victims feelings of fear, anguish and inferiority capable of humiliating and debasing them and possibly breaking their physical or moral resistance" 27 . The same court described the elements of degrading punishment in another case as:

1. Treating the victim as an object in the power of the authorities;

2. Constituting an assault on precisely that which it is one of the main purposes of Article 3 of the European Convention on Human Rights to protect, namely a person's dignity and physical integrity;

\section{Having adverse psychological effects;}

4. And inflicting anxiety and frustration upon the victim.

Given the abovementioned legal proceedings concerning ill-treatment in the European Convention on Human Rights, it can be inferred that a single treatment, as discussed with regard to the techniques of interrogation in the case of Ireland v. UK as well the case of Tomasi v. France, may be both degrading and inhuman at the same time. The Commission stated in the Greek case that all acts of torture considered as degrading and inhuman treatment and all instances of inhuman treatment are also degrading ${ }^{28}$. However, all degrading treatments or punishments

\footnotetext{
22 Ibid., para. 504

${ }^{23}$ Ibid., para. 507

${ }^{24}$ ICTY, Appeals Chamber, Judgment, The Prosecutor v. Zlatko Aleksovski, IT.95-14/1-T para 23/1-57

${ }^{25}$ ECtHR, Ireland v. UK. Publications of the European Court of Human Rights, Series A: Judgment and Decisions, vol.25, p.65;58 ILR 188 at 264;ECtHR, Tyrer case in Judgments and Decisions vol.26,p.14,58 ILR 339 at 352 ECtHR, Case of Campbell and Cosans, in Judgments and Decisisons, vol 48. P.13;67 IRL

480 at 492;ECtHR, Selcuk and Asker v. Turkey. Reports of Judgments and Decisisons, 1998 II, p.910.

${ }^{26}$ ECtHR, The Greek case, (1972) 12 Year Book of the Convention on Human Rights, p. 186. (cf. ECtHR., Ireland V. UK, (1976)19YearBook of the Convention on Human Rights, p.748; 58 ILR 188 at 265.)

${ }^{27}$ ECtHR, Ireland V. UK, Publications of the European Court of Human Rights, Series A. Soering case, in Judgments and Decisions vol. 161, para.100, p.39.98 ILR 270 at 307. ECtHR, Case of Campbell and Cosans, in Judgments and Decisions, vol. 48., p.13; 67 ILR 480 at 492 In this case, it was stated that a treatment is considered degrading only if a minimum level of degradation or humiliation is inflicted upon the victim before their eyes or other persons. This assessment of this minimum level depends on the circumstances of the case.

${ }^{28}$ ECtHR, the Greek case, (1972) 12 Year Book of the Convention on Humen Rights, p.186.
} 
are not necessarily inhuman and do not meet the requirements to be considered as torture ${ }^{29}$.

-UN Human Rights Committee and the Inter-American Human Rights System

Both the Inter-American Commission and the Inter-American Court of Human Rights have evaded a clear differentiation between torture, inhuman treatment, and degrading treatment mentioned in Article 5 of the American Convention on Human Rights ${ }^{30}$. Following the Committee on Human Rights, the American Court has also applied these notions with reference to the events in a number of cases. In these cases, these institutions limited themselves to the consideration of whether the right to receive humane treatment was violated or not.

The above sources lead us to conclude that no practical distinction has been made between degrading and humiliating treatment and it seems that the elements of humiliation are the same as the elements of degrading treatment. The following list, which was inferred from human right cases, specifies what acts can be regarded as humiliating and degrading treatment.

\section{Different forms of racial discrimination. ${ }^{31}$}

2. Certain techniques of interrogation that inflict psychological anxiety upon the victim and lead to inhuman treatment (e.g. hooding the detainees, making them stand against a wall, exposing them continuous noise, deprivation of sleep, and restriction on food and water). ${ }^{32}$

3. In the case of Hurtado v. Switzerland, a stun grenade was used to detain the applicant, as a result of which he excreted and dirties his clothes. The fact that only after one day he found the opportunity to change his clothes was considered by the Commission as degrading treatment. ${ }^{33}$

\section{Certain types of corporal punishment. ${ }^{34}$}

5. Unlawful treatments in the prison with the aim of humiliating the prisoners and creating in them a sense of insecurity (solitary confinement and continuous transfer to colder parts of the prison). ${ }^{35}$

6. Hanging naked and handcuffed women from the ceiling or making them stay in a degrading position for a long time. ${ }^{36}$

In what follows, we will mention a number of cases belonging to the trials after World War II.

In the case of K. Malzer, the accused was convicted of violence, insulting, and public curiosity against Article 2(2) of Geneva Convention of 1929. The prisoners had been forced to march in the streets of Rome. ${ }^{37}$

In the case of $\mathrm{T}$. Chuchi and others, the accused was prosecuted for ill-treatment of Sikh prisoners through shaving their hair and beard as well as forcing them to smoke, given that these are forbidden in Sikhism (Articles 2, 3, 16, 46(3), and 54 of Geneva Convention of 1929 as well as Article 18 of Hague Conventions of 1907) ${ }^{38}$.

In the case of Schmidt, the accused was convicted of intentional, criminal, and voluntary participation in ill-treatment of the dead bodies of war prisoners. The dead bodies were dismembered and deprived of a

${ }^{29}$ ECtHR, Tyrer case, Publications of the European Court of Human Rights. Series A: Judgments and Decisions vol. 26, para. 29, p. 14;58 ILR 339 at 352 .

${ }^{30}$ S. Davidson, "The Civil and Political Rights Protectes in the Inter-American Human Rights System"; In D. Harris and S. Livingstone (eds.), The Inter-American System of Human Rights (Clarendon Press, Oxford, 1998), p.230.

31 ECtHR, East African cases 3 EHRR 1973 Com Rep. P. 76;C M D H (77).

32 ECtHR , Ireland v. UK, Publications of the European Court of Human Rights, Series A : Judgments and Decisions vol.25, p. 96; 58 ILR 188 at 239.

33 ECtHR, Hurtado v. Switzerland, Publications of the European Court of Human Rights, Series A : Judgments and Decisions, vol. 2, 80-A.P.14.

34 For more details see:

O’Boyle and Warbrick, Law of the European Convention on Human Rights, pp.81: ECtHR, Tyrer case, Publications of the European Court of Human Rights, Series A: Judgments and Decisions vol.26.

pp. 16 ff;58 ILR 339 at534; ECtHR, Costello-Roberts v. UK, in Judgments and Decisions vol. 247-C, paras. 29-32, pp. 59-60/ ECtHR, Y.v .UK, in Judgments and Decisions vol247-A,Con Rep, paras. 37-46, pp.12-14)

${ }^{35}$ Conetris v. Urugay, Communication No.139-1983, Report of the Human Rights Committee, UN Doc. A/40/40, paras. 9.2-10, pp.201-2.

${ }^{36}$ ArzundaGliboa v. Uruguay, Communication No.147/1988, /41/40, Para. 4.3.and 14, pp-130 and 133; Soriano de Bouton v. Uruguay, Communication No37/1978, Report of the Human Rights Committee, UN Doc.A/36/40, paras 2.5 and 13, pp. 144 and 146; 62ILR 265 at 257 and 258 .

37 In UNWCC,LRTWC, vol. XI, pp.53 ff: 13AD 289.

38 UNWCC,LRTWC, vol. XI, pp.62.ff. 
respectful burial. ${ }^{39}$

\section{Element of Mental State (Mens Rea)}

Long-terms deprivation of lavatory within the dormitories of Camp 9 is sufficient for the mens rea of this crime to be realized. Therefore, the assumption that Iraqi forces did not have intent to continue the situation for four and a half years is automatically rejected. General misintent is of course enough for the realization of this crime and general misintent is not needed.

Intent is of two kinds: general and specific. General intent refers to the perpetrator's voluntary act or omission. Thus, not building lavatories within the dormitories was an intentional and voluntary omission. It cannot be accepted in no way that this omission had took place as a result of negligence or forgetfulness. The nature of lavatory is such that nobody can deny its necessity. Consequently, it is obvious that this omission was intentional and voluntary.

The notion of specific intent determines whether perpetration of the crime requires a specific misintent or not. In this case, the crime in question does not require any specific misintent; that is, the perpetrator needs not have intent to degrade and humiliate, but mere degrading treatment is sufficient. To put it more clearly, not building a lavatory within the dormitories of the camp needs not be aimed at humiliating, degrading, or even harassing the prisoners, but the omission per se is a realization of crime.

\section{According to ICTY,}

In the prosecution of an accused for a criminal offence, the subjective element must be tempered by objective factors; otherwise, unfairness to the accused would result because his/her culpability would depend not on the gravity of the act but wholly on the sensitivity of the victim. Consequently, an objective component to the actus reus is apposite: the humiliation to the victim must be so intense that the reasonable person would be outraged. ${ }^{40}$

In the case of Aleksovski, ICTY also stated that,

Recklessness cannot suffice; the perpetrator must have acted deliberately or deliberately omitted to act but deliberation alone is insufficient. While the perpetrator need not have had the specific intent to humiliate or degrade the victim, he must have been able to perceive this to be the foreseeable and reasonable consequence of his actions. ${ }^{41}$

In the case of Kunarac and others, ICTY stated that "the Trial Chamber's observations in the Aleksovski case on the mental element of the offence of outrages upon personal dignity do not provide an unambiguous statement of what it considered the relevant mens rea to be"42. ICTY emphasizes that the mental element of the offence does not involve any specific intent to humiliate, ridicule or degrade the victims ${ }^{43}$. Following is the conclusion of the court after considering the legal proceeding.

The Trial Chamber is of the view that the requirement of an intent to commit the specific act or omission which gives rise to criminal liability in this context involves a requirement that the perpetrator be aware of the objective character of the relevant act or omission. It is a necessary aspect of a true intention to undertake a particular action that there is an awareness of the nature of that act. As the relevant act or omission for an outrage upon personal dignity is an act or omission which would be generally considered to cause serious humiliation, degradation or otherwise be a serious attack on human dignity, an accused must know that his act or omission is of that character - i.e. that it could cause serious humiliation, degradation or affront to human dignity. This is not the same as requiring that the accused knew of the actual consequences of the act.

In practice, the question of knowledge of the nature of the act is unlikely to be of great significance. When the objective threshold of the offence is met - i.e. the acts or omissions would be generally considered to be seriously humiliating, degrading or otherwise a serious attack on human dignity - it would be rare that a perpetrator would not also know that the acts could have that effect.

In the view of the Trial Chamber, the offence of outrages upon personal dignity requires

\footnotetext{
${ }^{39}$ In UNWCC,LRTWC, vol. XI, pp.151 ff:13 Ad 289.

${ }^{40}$ ICTY, Judgment, The Prosecutor v. Zlatko Aleksovski, IT.95-14/1-T.para.56.

${ }^{41}$ ICTY, Judgment, The Prosecutor v. Zlatko Aleksovski, IT.95-14/1-T para56.

${ }^{42}$ ICTY, Judgment, The Prosecutor v. Dragoljub Kunarac and Others, IT.96-23/1-T para. 508.

${ }^{43}$ Ibid, para. 509.
} 
(i) that the accused intentionally committed or participated in an act or omission which would be generally considered to cause serious humiliation, degradation or otherwise be a serious attack on human dignity, and

(ii) that he knew that the act or omission could have that effect. ${ }^{44}$

It seems that mere violation of humanitarian laws is sufficient to prove the perpetration of a war crime and lack of knowledge of the fact that this act or omission is forbidden cannot contribute to the vindication of the perpetrator. 45

\section{Conclusion}

In conclusion, we understand that the rights of war prisoners are recognized in international documents, not least in Geneva Convention of 1949, and these rights must be respected by all countries. If any of these rights are violated, a war crime would result. However, the wording of the relevant articles of the statutes of war crime tribunals, particularly the ICC statute, is not without ambiguity. As mentioned above, different courts offer varying interpretations of their statute in different cases. These variations are reflected above all in actus reus and mens rea of the crime. My imprisonment in Iraq and experiences of difficult circumstances motivated me to try to illustrate how lack of some basic facilities may turn into a war crime. At first glance, lack of lavatory within the dormitories of a prisoners' camp may not appear to be a war crime. On closer inspection, however, the humiliating consequences and outrages upon human dignity will become clear. Geneva Convention (III) of 1949 stipulates that the detaining power is obliged to intern the prisoners in conditions which resemble those of its own military forces. Negligence in fulfilling this obligation in form of omission may convict the detaining power on a war crime. As mentioned above, the decision not to build lavatories within the dormitories of Camp 9 as well as its negative consequences was an instance of war crime. The officers of the Red Cross, however, frequently visited the camp and took no measure to solve the problem. This might be explained by the fact that the various types of war crime are still ambiguous and need to be further investigated and defined.

\section{Copyrights}

Copyright for this article is retained by the author(s), with first publication rights granted to the journal.

This is an open-access article distributed under the terms and conditions of the Creative Commons Attribution license (http://creativecommons.org/licenses/by/4.0/).

\footnotetext{
${ }^{44}$ Ibid, paras. 512-14.

${ }^{45}$ Ghorban-nia, N. Hoghugh-e Bashar va Hoghugh-e Bashar-doustaneh [Human Rights and Humanitarian Law], Tehran: Research Center of Islamic Culture and Thought, 1387/2008, p. 428.
} 